\title{
Influence of catchment processes on fluvial morphology and river habitats
}

\author{
Askoa Ibisate $^{1, *}$, Alfredo Ollero $^{2}$ and Elena Díaz ${ }^{1}$ \\ ${ }^{1}$ Section of Physical Geography, Dept. of Geography, Prehistory and Archaeology, University of Basque \\ Country, Tomás y Valiente s/n, 01006 Vitoria-Gasteiz. \\ ${ }^{2}$ Section of Physical Geography, Dept. of Geography and Land Management, University of Zaragoza, Pedro \\ Cerbuna s/n, 50009 Zaragoza.
}

* Corresponding author: askoa.ibisate@ehu.es

Received: $18 / 3 / 2010 \quad$ Accepted: 8/2/2011

\begin{abstract}
Influence of catchment processes on fluvial morphology and river habitats

Fluvial morphology is conditioned by three basic elements: flow regime, sediment yield and valley characteristics. These elements are controlled by factors operating at different spatial and time scales, within and outside of the basin. Moreover, the great influence of human activities has to be considered as they presently constitute one of the main hydromorphological factors. This paper synthesises the effects of different variables on fluvial morphology and structures the review around the three basic elements mentioned above with examples from the Iberian Peninsula rivers. Understanding the factors that affect channel morphology is of primary importance for assessing river habitat condition, considering that river reach characteristics are the result of the interaction between upstream and downstream catchment and local conditions. Finally, fluvial geomorphology is a key element in river ecosystems that creates geodiversity and heterogeneity of fluvial forms at different spatial scales (i.e., river habitats) and should be considered part of our natural heritage and a valuable natural element itself.
\end{abstract}

Key words: Fluvial morphology, flow discharge, sediment yield, valley characteristics, catchment variables, Iberian Peninsula rivers.

\section{RESUMEN}

Procesos de cuenca como condicionantes de la morfología fluvial y de los habitats fluviales

La morfología fluvial está fundamentalmente condicionada por tres elementos: caudales líquidos, aportación sedimentaria y las características del valle; estando al mismo tiempo determinados por variables que operan fuera y dentro de la cuenca. Finalmente, la actividad humana perturba de forma considerable la morfología fluvial, siendo uno de los elementos con mayor capacidad de alteración hoy en día. En este artículo se presenta una síntesis de las variables que condicionan la geomorfología fluvial, estructuradas en torno a los tres parámetros principales y se proporcionan algunos ejemplos de ríos de la Península Ibérica para ilustrarlos. La comprensión de los factores que condicionan la morfología de un cauce resulta de mucha importancia para un buen diagnóstico de las condiciones del hábitat fluvial, considerando que las características de un tramo son el resultado de la interacción de las condiciones locales, así como de la cuenca aguas arriba y la situación aguas abajo del mismo. Finalmente, la geomorfología fluvial es un elemento clave en los ecosistemas fluviales, crea geodiversidad y heterogeneidad en las formas fluviales a diferentes escalas espaciales, como los hábitats fluviales, forma parte de nuestro patrimonio natural y constituye un valor natural en sí mismo.

Palabras clave: Geomorfología fluvial, caudal, disponibilidad de sedimentos, características del valle, variables de cuenca, ríos de la Península Ibérica. 


\section{INTRODUCTION}

Fluvial morphology results from the complex interplay of all geomorphic processes that occur in a basin at different spatial and temporal scales (Schumm, 1988; Piégay \& Schumm, 2003; Church, 2008; Schumm \& Lichty, 1965; Lane \& Richards, 1997). The variables that affect stream systems, such as climate, geology, vegetation, valley dimensions, hydrology, channel morphology and sediment load, have different causal relationships one with another, depending upon the time scale of analysis (Amoros \& Petts, 1993; Gilvear \& Bravard, 1993). However, channel form in particular is mainly a result of the interaction between river flows, sediment yields (driving variables), valley characteristics (boundary characteristics) and human activity upstream, downstream and at the site (Newson, 2002). Any change in these elements or processes results in new dynamics and river forms.

Drainage basins have long been described based on the main geomorphic driving processes of erosion, transport and sedimentation (Schumm, 1977; Gregory \& Walling, 1973). More recently, different authors have reviewed the influence of the drainage basin in fluvial channels, relating reach hydraulic geometric characteristics to these main geomorphological processes and taking into account that hillslope influences the variability of different variables along the drainage system such as vegetation and other ecological processes (Church, 2002; Brierley \& Fryirs, 2005). In this regard, Brierley \& Fryirs (2005) have proposed a scaled hierarchical approach to derive river style properties from empirical geomorphological surveys of a basin's sediment dynamics, in which natural channels are defined as those "dynamically adjusted" and working within a range of "variability set by the river style" and the "catchment context".

Stream channels tend toward an equilibrium state in which the inputs of mass and energy equal the outputs. Thus, any change in sediment yield, flows or slope leads to an adjustment of the channel by means of changes in channel size, shape and profile through erosion and deposition of sediments (Montgomery \& Buffington, 1998).
Rivers are subject to geomorphic thresholds of several types that define significant changes in the driving processes and river morphology and delimit distinctive riverine landscapes and habitats (Church, 2002). Short-lived states of disequilibrium often result when a geomorphic threshold is exceeded by changing the behaviour of any variable or process inside or outside of the system (Renwick, 1992).

The balance of Lane (1955) shows the relationships among flow, quantity and size of sediment and slope, according to which, if the sediment supply and size of bed material are higher than the flow capacity needed for transport, deposition and aggradation processes will occur until the system is adjusted to a new equilibrium between discharge and sediment supply. In contrast, if the amount of sediment is low, the bed material size decreases or discharge increases, the flow energy will exceed that needed for transport and erosion and incision processes will dominate. Finally, if sediment load and flow are in balance, neither channel erosion nor deposition will occur. In this case, bed or bank erosion/deposition could balance the sediment amount depending on the material. However, Lane's equation does not indicate where exactly erosion or sedimentation processes will occur and, therefore, how the channel form might change (Simon \& Castro, 2003). The balance of sediment supply and transport capability, conditioned by gradient and discharge (Leopold \& Wolman, 1957) among other characteristics, influences channel bed structure and the style or planform of the channel, which in turn create distinctive fluvial forms and physical habitats in different parts of the river network (Church, 2002). In this regard, discriminant lines between channel form planforms may be indicative of key thresholds that determine different morphologies and habitat features (Church, 2002).

The main objective of this paper is to review the effects of basin-scale processes on the creation of fluvial morphology and provide illustrations of different examples taken mainly from the Iberian Peninsula Rivers but also from other geographical areas. This review emphasises the importance of the balance between sediment yield and water in fluvial morphology and pinpoints 
how these variables are influenced by a wide array of external and internal catchment processes and human activities. Thus, the intention of the review is to update and clarify the basic geomorphological concepts that need to be addressed when managing and restoring fluvial ecosystems.

\section{KEY FLUVIAL SYSTEM VARIABLES FOR CHANNEL MORPHOLOGY}

Fluvial geomorphological processes and channel forms are determined by three main factors: discharge and sediment yield, which are the main drivers, and valley characteristics, which establish the boundary conditions (Newson, 2002). These factors are influenced by other variables within and outside of the catchment and by different human activities that frequently dictate the character of riverine landscapes (Church, 2002; Fig. 1).

\section{Basin external factors}

Climate, tectonics, base level and past environmental conditions are all factors that operate at a scale larger than the catchment (Fig. 1) but that are very important as they control inputs and rates of matter and energy. Therefore, any change in these variables will lead to a complex sequence of changes and adjustments within the fluvial system (Charlton, 2008).

\section{Climate}

Climate is an important factor that controls river hydrology. The climatic conditions, rainfall regime, type of precipitation, extreme events, frequency and magnitude of rainstorm and droughts all determine flow generation and erosion capacity and, thus, the delivery of sediments to the channel and transport. Climate also has an important influence on the type and density of vegetation, soils and land use, all of which control runoff generation and sediment yield.

As an example, the Iberian Peninsula consists of a wide variety of fluvial regimes that respond to the climate regime, principally to rainfall and including regimes due to extreme events. For example, rivers with nival regimes such as those in the Pyrenees, "ramblas" or creeks with low

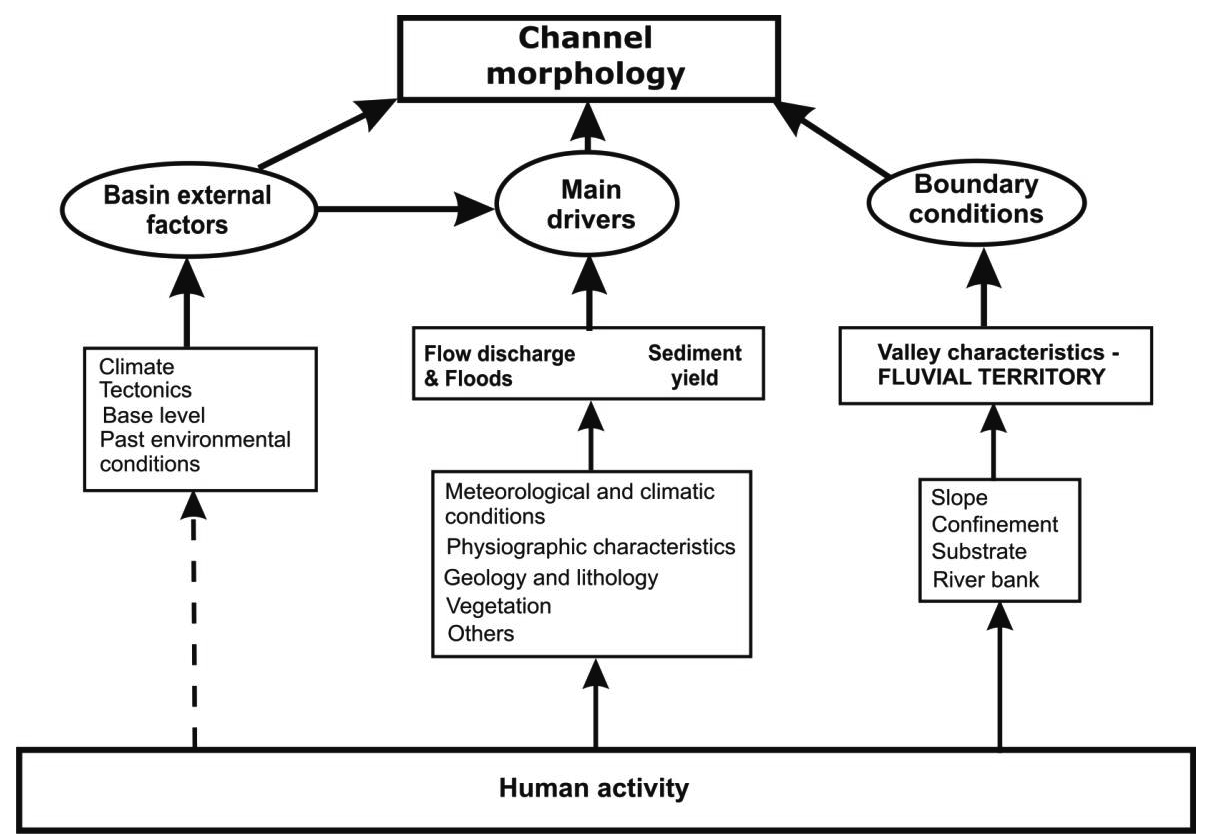

Figure 1. Schematic representation of the main factors that determine channel morphology in fluvial systems. Representación esquemática de los principales factores que determinan la morfología fluvial. 
and irregular flows that are common in the eastern and southern part and streams with oceanic regimes that are common in the Atlantic basins. Thus, in these cases, the morphologies are conditioned by the competence to transport sediments, which is mainly determined by water discharge (Fig. 2). The discharge regime varies seasonally and synoptically, from low flows that decrease the water level to higher flows that can overbank, leading to the "flood pulse" process that is necessary for the exchange of matter and nutrients between the main channel and the floodplains (Junk et al., 1989).

\section{Tectonics}

Tectonic activity, including uplift, tilting or subsidence, affects fluvial morphology and the river planform directly by changing gradients and determining topography, river profile and slope and indirectly by altering the sediment budget through changes in erosion, transport or sedimentation rates due to new gradient conditions or by mass movements that generate obstacles in the channel (Schumm, 2005). The effects of tectonic activity are not only given at the reach level; they instead trigger changes that progress upstream and downstream until the river channel establishes a new equilibrium profile. Several authors have provided examples of the adjustment of fluvial morphology in areas with high tectonic activity, as illustrated by Schumm (2005) for the alluvial plain of the Sindh River in the lower Indus. For the Iberian Peninsula, Díez Herrero (2003) described the influence of tectonic activity on the morphology of the Alberche River in central Spain, and Maher \& Harvey (2008) illustrated changes in the Alias River, which is southeast of the Iberian Peninsula.

\section{Base level}

Lowering or raising the base level implies changing the equilibrium line. Base-level changes can occur at a regional or local scale. At a regional scale, the main causes include tectonic uplift or subsidence, changes in sea level or isostatic uplift of land masses (Schumm, 1993; Blum \& Toèrnqvist, 2000; Florsheim et al., 2001; Friedman et al., 1996; Rinaldi \& Simon, 1998; Doyle \& Harbor, 2003; Springer et al. 2009), while local baselevel changes can occur naturally when aggrada-

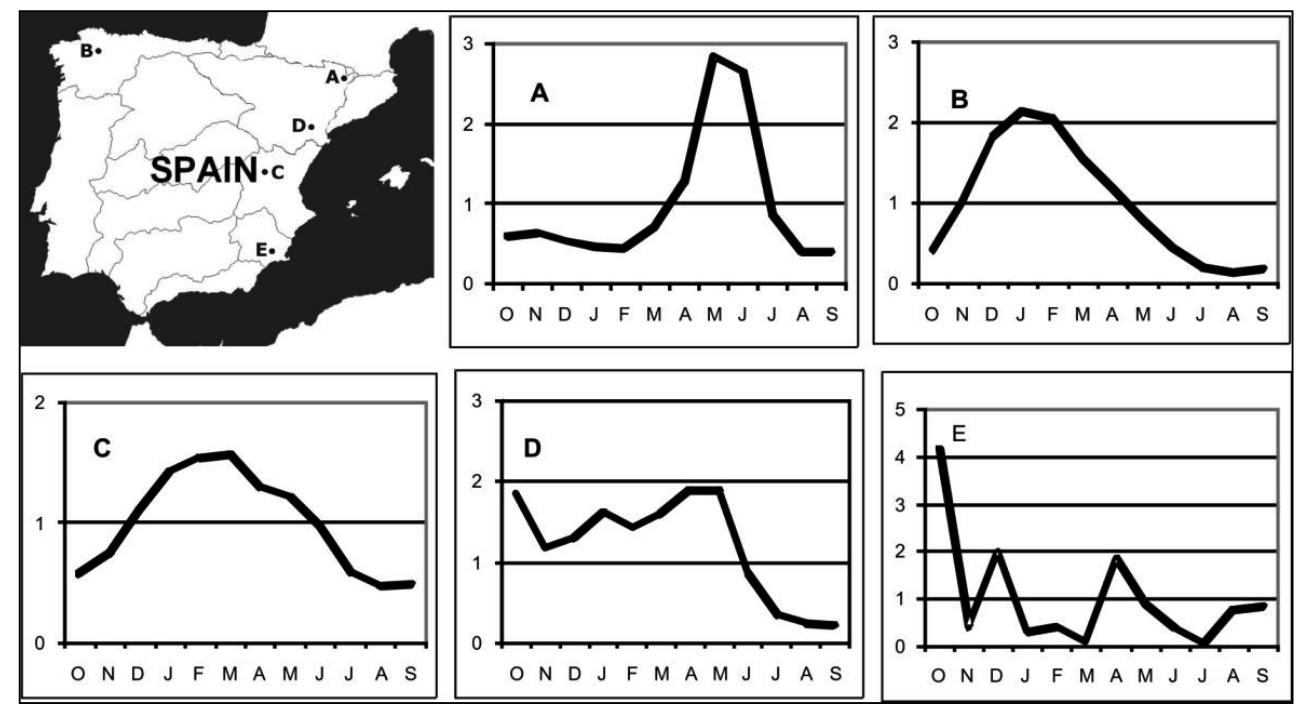

Figure 2. Monthly flow coefficient for snowmelt (A: Valira River), pluvial oceanic (B: Mino River), pluvial continental (C: Cabriel River), pluvial Mediterranean (D: Matarana) and ephemeral (E: Rambla Algeciras) hydrological regimes of the Iberian Peninsula. Regímenes hidrológicos de la Península Ibérica: nival (A: río Valira), pluvial oceánico (B: río Miño), pluvial continental (C: río Cabriel), pluvial mediterráneo (D: río Matarraña) y efímero (E: rambla Algeciras). 
tion or incision in the main channel alters the base level of its tributaries or by human activity, as for example, with the construction of dams (Fig. 3).

The natural lowering of a river base level could rejuvenate a drainage network, forcing regressive erosion upstream to achieve a new equilibrium line. However, a rise in base level would lower energy and thus result in more depositional processes, mostly in lower reaches, and in alterations of channel planforms (Lane, 1955; Schumm, 2005). Some of the best understood examples of natural changes in base level are those that occur as a result of glacioeustatic changes, such as those that led to the formation of the Upper Ebro canyons during the end of the Tertiary. The intense cold conditions at the beginning of the glaciations led to important incision when the Ebro River base level dropped, a process that was accelerated by karstic processes (González Pelle- jero, 1986). Recently Garzón et al. (2010) have also shown the base level control of Tertiary depressions on the Guadiana River incision.

Dams can also change the base level upstream and downstream. Upstream, aggradation processes dominate, and the dam itself produces lentic waters with their associated forms and habitats. Downstream, decreased discharge and sediment load result in incision, channel narrowing and encroachment of plants. A good example of this process can be seen along the Aragón River downstream of the Yesa dam, and the process is repeated due to the many hydropower stations located along the entire reach downstream of the Yesa dam. The hydropower stations with their dams and derivation channels create water diversions and alterations of sediment transport and, therefore, lead to different processes in each part (Fig. 3). Upstream, the

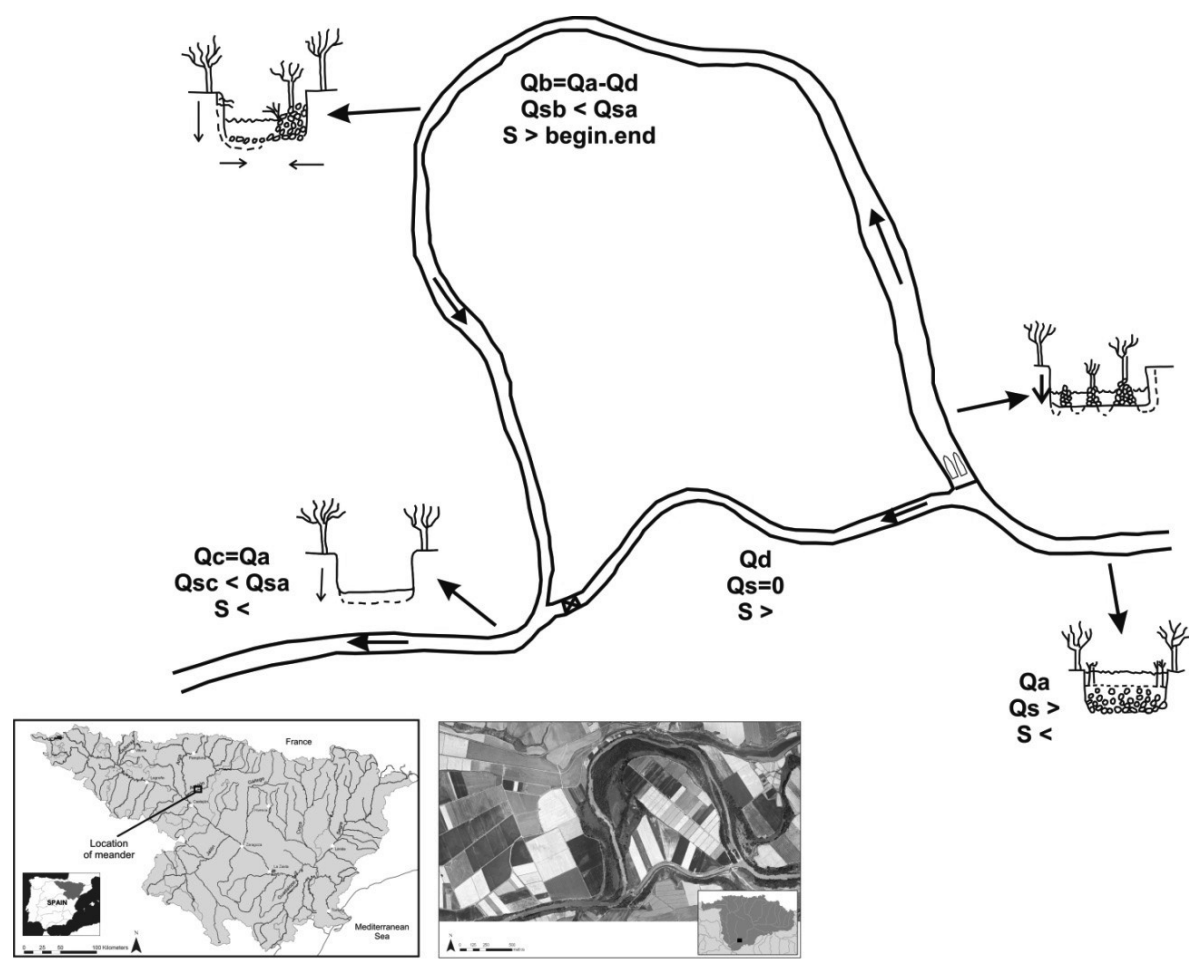

Figure 3. Aerial picture showing a small hydroelectrical station sited in Mélida on the lower reach of the Aragón River (Ollero et al., 2008) and a schematic representation of dam and water abstraction effects (Qs: solid charge, S: slope, Qa: discharge upstream of the dam, Qb: discharge in the short-circuited reach, Qd: derived discharge, Qc: discharge downstream of the confluence of derived flow). Fotografía aérea y esquema de los efectos hidromorfológicos de presas y detracciones de aguas en una minicentral hidroeléctrica de Mélida situada en el tramo bajo del río Aragón (Ollero et al., 2008). Qs: caudal sólido, S: pendiente, Qa: caudal aguas arriba del azud, Qb: caudal en el tramo cortocircuitado, Qd: caudal derivado, Qc: caudal aguas abajo de la confluencia del flujo derivado. 
dam traps sediments, reduces the slope and slows water velocity. Therefore, sediments are accumulated, and the waters become stagnant, creating lacustrine forms and habitats. Downstream, water discharge is considerably decreased, and thus, sediment load and water transport capacity are altered. The slope also increases downstream producing vertical erosion and narrowing processes; therefore, new bars emerge, and vegetal colonisation increases. Finally, once the diverted waters converge with the river, water discharge is recovered but not sediment load, which produces vertical erosion processes and a drop in sediment load, affecting downstream processes and forms.

\section{Past environmental conditions}

Every drainage basin has a historical legacy resulting from past environmental changes. This legacy includes the cumulative effects of processes such as erosion, transport and deposition over long periods of time and the influence of factors external to the basin such as climatic variations since the Last Glacial Maximum. This past legacy has greatly affected fluvial systems worldwide, and many existent river morphologies may have been constructed by these past processes (Newson, 2002). Past climate conditions, not only in relation to precipitation but also to temperature, snow and glacial activity, have shaped valley bottoms and left relict sediment deposits on hillslopes and floodplains, which can easily be dragged to the channel. The form of some braided rivers is a consequence of previous climate conditions, in which higher erosion rates yielded more material than the amount of sediment that these channels can transport presently. There are many cases in the Iberian Peninsula that illustrate this process. For example, past glacial activity in the Belagua River valley and the important weathering that the basin experienced have produced a flat valley bottom and an important sediment yield and delivery to the channel, which has resulted in a braided river planform. Another classic example is provided by the Mississippi River metamorphosis, in which the supply of huge amounts of meltwater and sediment from the ice sheet together with the lowering of the base level as a consequence of the subsidence of the sea level to approximately $150 \mathrm{~m}$ have repeatedly modified the channel planform (Fisk, 1944). A similar example is found in the Aguas River of southeastern Spain, in which past climatic changes linked to base level changes have given different fluvial dynamics and terrace levels (Schulte, 1996). Thus, applied fluvial geomorphological surveys and evaluations of the historical context of each basin and site are vital contributions to the understanding of existing river forms (Newson, 2002).

\section{Main channel morphology drivers}

River channel morphology is mainly controlled by the interaction between discharge regime and sediment budgets, which are also influenced by a wide array of factors from the reach, the valley and catchment characteristics or external factors.

\section{Flow, floods and sediment discharges}

The interaction between discharge and sediments governs erosion, transport or sedimentation processes. Therefore, variation of flow regimes or sediment budgets results in different river channel morphologies. Floods are a principal element in fluvial functions as they accelerate the geomorphological dynamics of erosion, transport and sedimentation processes as well as the ecological interactions that depend upon these processes (Junk et al., 1989). Ordinary floods and bankfull discharges are extremely important for shaping channel forms due to the high velocity of water, while low flows and large floods give the channel its final form due to their high competence. Sediment load is the other factor that controls channel morphology, as erosion and sedimentation of material shape and form geomorphic features. Sediment load changes according to delivery from the upstream basin. Once the sediments get into the channel, their transport regime and the character of alluvial deposits along the channel depend on the amount and size of sediments (Church, 2002), and the transport is mainly classified as suspended, mixed or bedload. These sediment transports are related in different ways to 
flows, and each gives different morphological responses (Schumm, 1977). Therefore, any factor affecting the hydrological response and sediment delivery of a basin and therefore discharge and sediment yields will influence the channel geomorphological conditions. Finally, these factors are also modified by human activity either directly, as occurs by water diversion, or indirectly, as a result land use changes, for example.

Flow and sediment regimes are mainly influenced by rainfall regimes. Rainfall conditions, overland flow and the amount of water determine the erosive capacity of the water and the availability of sediment. However, the runoff produced during a precipitation event and the hydrological response of a river depend on the particular form of the rainfall event, and thus, rainfall intensity, duration and type of precipitation also play an important role. Higher sediment yield rates are obtained during flood events in which runoff increase erosion and transport of sediment. Moreover, higher runoff produces higher discharges that are able to shape morphological features by remobilising, scouring or depositing them further away. The relationship between discharge and sediment concentration is, nevertheless, extremely complex, as sediment availability depends on many factors and not simply on water runoff.

Physiographic or morphometric characteristics of the catchment (e.g., shape or topography) also determine flow and sediment regimes. These characteristics control the way flow arrives to the main channels, the time it takes, and the role of tributary confluences. For example, large debris flows can accumulate in the confluence of ravines with similar compactness indices and in highly erodible landscapes. One such large debris flow occurred in the confluence of the Calcín and Lopán ravines in the central Pyrenees, burying the church of the monastery of San Adrián de Sasabe (García-Ruiz \& Valero-Garcés, 1997).

Catchment lithology constitutes the source of materials that lay in the channel; thus, its resistance is one of the principal factors that determine sediment yield rates and the type of solid flow, which are variables that control to a great extent the hydrogeomorphological condition of river channels. Moreover, structural fac- tors (such as faults) and riverbed lithology control drainage patterns and the density of river networks. Bedrock channels are generally narrower (Turowski et al., 2008) because vertical incisions that follow weakness lines such as faults prevail over lateral movements. Many examples can be seen in the rivers that cross the mountain areas of the Iberian Peninsula, such as those in the "Sierra de Guara". However, rivers over granular beds are wider and have high sediment transport, as braided rivers such as the Eska River in Belagua mentioned previously. Moreover, lithology (i.e., bedrock type) can also exert great control over water runoff. Permeable soils and rocks such as karstic types have slower responses to precipitation events and maintain flow longer compared with impermeable types. In contrast, drainage basins with impermeable or saturated materials have faster responses to rainfall that result in higher peak flows and often in more extended droughts as well.

The type and density of vegetation has a very important role on runoff generation and soil protection. Vegetation cover reduces the impact of raindrops, increases interception and allows higher infiltration rates, which protects from soil erosion and reduces sediment production and water runoff. Therefore, in basins covered by dense vegetation, runoff generation, flow peaks and droughts tend to be less severe (Beechie et al., 2006). Large impacts on river morphology due to changes in vegetation cover and land use have been recognised, for instance, in the Pyrenees. An increased forest density results in reduced water discharge, sediment yield and load, and consequently, the channel form becomes simplified from braided to single. This phenomenon is especially evident in mountain areas (Piégay et al., 2009) and specifically in the Pyrenees, where it has been shown that changes in the structure and density of vegetation due to land use changes have produced alterations in the Ijuez and Aurin River forms (Martínez-Castroviejo et al., 1991). Moreover, vegetation can also greatly influence the floodplain, especially on river banks, protecting them from erosion (Gurnell et al., 2006). Although this factor can be considered as more of a valley characteristic condition, some authors 
such as Malavoi et al. (1998) developed their free space theory based on the supply of sediments that riparian erosion processes can generate once drainage basin deliveries due to land use and dams have disappeared.

\section{Valley characteristics and fluvial territory: boundary conditions}

As explained above, flow and sediment regimes are controlled by catchment variables; however, the results of their interaction are constrained by valley and reach variables such as valley morphology, slope, confinement, bed material and floodplain characteristics. Valley slope controls the potential energy of a reach and influences incision and aggradation processes that lead to different channel equilibrium profiles (Charlton, 2008). Moreover, changes in valley floor materials due to differences in bedrock hardness or the presence of tributary confluences also produce river channel adjustments to the terrain convexities and concavities on the valley floor. A good example of this effect is provided by the AragónSubordan River in the western Pyrenees, where changes in the slope and valley confinement along the course of the river are the main factors that generate contrasting planform patterns, and therefore, river forms. Thus, in its headwaters at the site named Aguas Tuertas, an anastomosing pattern occurs in a low gradient reach formed of soft glacial materials in a U-form valley. Further downstream, the river crosses the "Garganta de los Infiernos" gorge over limestone materials. In this case, the river adapts to new gradient, valley confinement and bedrock material conditions and produces a single, straight mountain river channel with the bed mainly composed of coarse materials (Ollero et al., 2003; Díaz et al. 2005, 2006).

Valley width and valley floor shape determine valley confinement, which is a very important boundary condition for channel morphology. River channel forms in confined valleys are restricted by valley walls (Thorne, 1997) that may increase flow resistance and sediment inputs because of the proximity of hillslopes to the channel. Therefore, if sediment yield exceeds flow transport capacity, alluvial deposits are usually formed. In partly confined valley settings, floodplains are discontinuous and lateral migration and floodplain development is possible; however, there is still some control by valley walls or hillslopes that can limit channel mobility and flood-associated processes. Finally, in accumulation zones and unconfined streams, hillslopes have relatively little influence on channel load because most of it is supplied from upstream sources or from riverbank erosion.

Moreover, Nanson \& Croke (1992) related floodplain confinement degree to stream power and sediment character. A good example of how valley confinement controls channel morphology is found in the comparison between different reaches of the Aragón River that have contrasting specific stream power and boundary shear stress. These variables are directly affected by valley confinement and are markedly different from the Aragón River at Gallipienzo $\left(3.57 \mathrm{~W} / \mathrm{m}^{2}\right.$ and $5.33 \mathrm{~N} / \mathrm{m}^{2}$, respectively), a confined river reach, and at Caseda $\left(0.55 \mathrm{~W} / \mathrm{m}^{2}\right.$ and $1.63 \mathrm{~N} / \mathrm{m}^{2}$, respectively), an unconfined river reach. These differences result in distinctive geomorphological features that distinguish each floodplain type in terms of genesis and resulting morphology (Nanson \& Croke, 1992). At Gallipienzo, we find a confined straight channel with higher transport capacity and fewer morphological units, while at Caseda, there is a meandering planform with its associated forms such as scroll bars.

Finally, riparian vegetation also influences channel morphology in different ways. Vegetation protects banks from erosion and increases flow resistance by increasing roughness and reducing flow velocities so that channels with dense riparian forests tend to be narrower (Brookes et al., 2000). Moreover, vegetation on river banks and woody debris within the channel may act as sediment traps that create different channel morphologies and modify the channel type (Schumm, 2005). The introduction of woody debris into the Añarbe River has considerably changed the fluvial morphology, creating a higher heterogeneity of geomorphological features and producing changes in sinuosity, e.g., the creation of new lateral bars upstream of wood jams (Elosegi et al., 2011). 


\section{Human activity and changes in fluvial geomorphology}

Human activity, at different scales from the catchment to the channel, has had an increasing influence on fluvial systems since the Neolithic (García-Ruiz \& Valero-Garcés, 1997; González $\&$ Serrano, 2007) to recent years (Ollero, 2007). All land uses and practices in the drainage basin (e.g., deforestation, agriculture, mining, urbanisation and fires) affect runoff and sediment yield (Charlton, 2008). In addition, other activities directly modify the channel and floodplain, such as dams, water abstraction, gravel mining, canalisation, dredging, embankment, or riprap. Few rivers are presently free of human influences.

One major impact of human activity on river channel form is caused by dams, and the Iberian Peninsula has one of the highest numbers of dams per inhabitant in the world. Channel morphology upstream from dams is drastically modified to that resembling a lake, while downstream, dams act as sediment traps that block the natural transport of sediments except for suspended and dissolved loads. Downstream "cleaned waters" increase erosion capacity, which results in incision, armouring and embeddedness of sediments (Rinaldi \& Simon, 1998). In Spain, a clear example of a large human impact on river form is found in the Ebro River delta. This delta seems to have been formed or enlarged partially as a result of intense forest clearing during the Middle Ages (Maldonado, 1983; Mariño, 1990), while now it is threatened by a lack of sediments as a result of the large retention produced by the many dams constructed in its main channel (Batalla, 2003; Day et al., 2006) and the effect of increased reforestation. The effectiveness of dams for sediment trapping is illustrated by the accumulation of sediments in many reservoirs worldwide (Martínez-Castroviejo \& García-Ruiz, 1990; Martínez-Castroviejo et al., 1990), which is becoming an important environmental problem (López-Moreno et al., 2003; Cobo et al., 1996). A clear example is the Barasona reservoir in the Ésera-Isábena catchment that shows important sediment-filling processes (Valero-Garcés et al., 1996-97).
Moreover, dams drastically modify discharge regimes depending on reservoir use and management, which mainly involve water supply, flood prevention or hydropower generation (LópezMoreno et al., 2003; Ibisate, 2004). Reservoirs for irrigation can completely reverse flow regimes and the timing of floods and base flow (López Bermúdez, 2004). In addition, flow reduction and decreased flood frequency and magnitude lead to the encroachment of vegetation, changes in sediment transport, changes in channel morphology, armouring and embeddedness (Brandt, 2000). The Yesa reservoir provides an example of how irrigation dams markedly alter flow regimes by decreasing discharge during spring and increasing it during summer; also affects flood frequency and magnitude, especially in ordinary floods (Fig. 4).
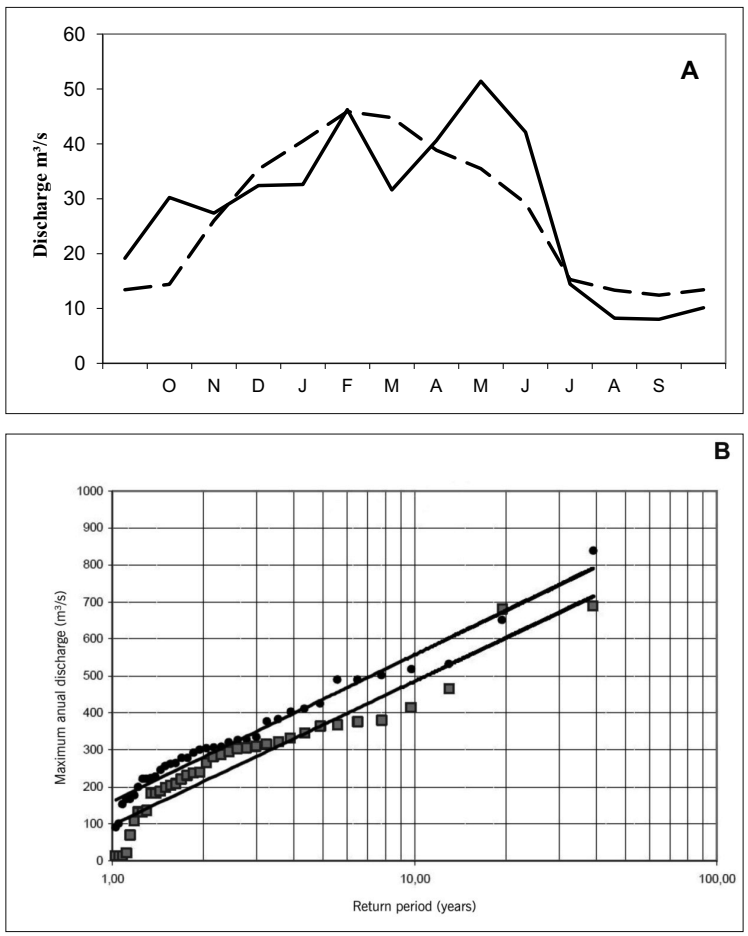

Figure 4. Mean monthly flow $\left(\mathrm{m}^{3} / \mathrm{s}\right)$ from the Aragón River upstream (- - -) and downstream (- - - ) of the Yesa Reservoir (A). Flood frequency curves for the Aragón River before (19121961: •) and after (1961-1998: $\mathbf{\square})$ the Yesa dam construction are also shown (Ollero et al., 2002) (B). Alteración del régimen hidrológico aguas arriba (- - -) y abajo (- - -) del río Aragón por impacto del embalse de Yesa. Curvas de frecuencia de inundación para el río Aragón antes (1912-1961: •) y después (1961-1998: ஐ) de la construcción de la presa de Yesa (Ollero et al., 2002). 
Land use such as forestry, agriculture and livestock grazing increase soil erosion, sediment yield, water runoff and peak discharges as a result of reduced infiltration rates. Moreover, other activities can have significant impacts on sediment yield; heavy machinery or trampling by livestock produce soil compaction and increase overland flows, and land drainage increases the velocity at which water runoff is transferred to the channel. Fire is another process that influences flow and fine sediment yield. Urbanisation has the most detrimental effect among soil uses on river channels, as it reduces soil permeability and increases peak flood magnitude. In addition, sediment delivery increases during construction, although it is reduced afterwards. All of these changes modify the main channel form drivers, both flow and sediment type and yield.

Dredging and gravel mining produce large impacts because they reduce the solid discharge of rivers and destroy geomorphological forms, which alters sediment storage sites. For instance, the Belagua River, which is a braided river in the western Pyrenees, has been severely affected by gravel mining, resulting in incision, embeddedness and armouring, processes that have propagated upstream and downstream and created environmental problems that have even affected the stability of a bridge downstream (Martin Vide et al., 2007, Fig. 5). Other activities such as river straightening, embankments or canalisation, which are often performed for flood protection or to improve navigation, highly modify river channel form and processes.

All of the factors discussed above produce a total metamorphosis in the morphology of many rivers and may even result in a change of style. A noteworthy example is the case of the Ain River in France (Fagot et al., 1989; Bravard \& Petts, 1993). The effects of reservoirs, the im-

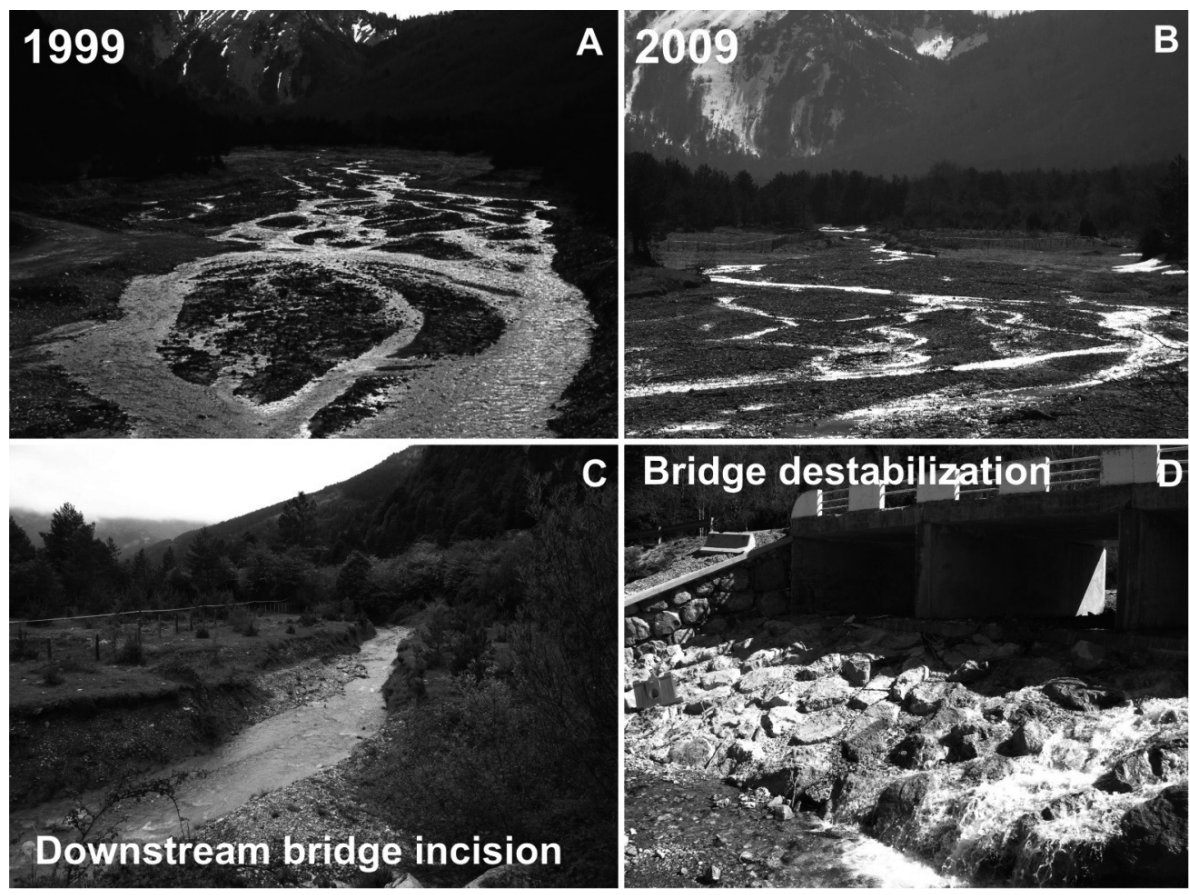

Figure 5. The pictures show the degradation of the braided channel of the Belagua River from 1999 (A) to 2009 (B) due to arid abstraction. These practices have reduced the alluvium quantity of the river bed and have resulted in incision processes upstream and channel narrowing (B), incision processes downstream of the bridge (C) and bridge destabilisation problems (D). La secuencia de fotografías muestra la degradación el cauce trenzado del río Belagua desde 1999 (A) a 2009 (B) debido a las extracciones de áridos. Dichas prácticas han reducido la cantidad de sedimentos aluviales lo que ha derivado en procesos de incisión y estrechamiento del cauce aguas arriba (B), así como procesos de incisión aguas abajo del puente $(C)$ y problemas de desestabilización de un puente (D). 
pact of structures on the control of bank erosion and other in-channel works converted a braided river to one that is straight with an important incision problem. A similar example is undergoing in the Gállego River due to gravel mining, land use changes and reservoirs (Martín Vide et al., 2010) or in the Arga River, where the decrease of sediment yield and transport due to land use changes and reservoirs linked to large river sections that are being canalised have transformed a free-meandering planform into a straight planform with heavy incision problems (Martín Vide et al., 2010; Ibisate et al., 2010).

\section{CONCLUDING REMARKS}

In this paper, we reviewed the effects of basinscale processes on the formation and maintenance of river channels and stressed the functional perspective of river hydromorphology. Throughout the paper, using examples from the Iberian Peninsula rivers and from other areas, we showed how river channels depend on a delicate balance between sediment yield and the transport capacity of water and how these drivers are very sensitive to a wide variety of external and internal catchment processes and human activities. Moreover, river channel forms provide the physical setting for river ecosystems, and changes in hydromorphology can have profound impacts on biodiversity and ecosystem functioning (Newson, 2002). Thus, we stress that river channel forms and processes should be seriously taken into account for sustainable river ecosystem management (Newson, 2002; Vaughan et al., 2009). For this purpose, it is necessary to completely understand the factors that drive channel morphology in order to obtain a good diagnosis of channel morphology conditions and thus, of river habitat characteristics. One must bear in mind that the channel form at the reach scale is the result of all of the upstream and downstream catchments plus the local conditions; thus, vertical, longitudinal and lateral connectivity are essential requirements for good river conditions and form. Therefore, because fluvial morphology determines ecological features, geomorpho- logical conditions strongly influence ecological status, and fluvial restoration often fundamentally involves geomorphological restoration. Finally, we stress the intrinsic value of geomorphology that, in addition to other functions, creates geodiversity, which constitutes an important part of our natural heritage.

\section{ACKNOWLEDGEMENTS}

We wish to thank José Barquín (Universidad de Cantabria), convenor of the Physical Assessment Methods in Rivers meeting, whose invitation to present this paper led to its creation. We also wish to thank the anonymous reviewers and Arturo Elosegi for their useful comments that have led to substantial improvements.

\section{REFERENCES}

AMOROS, C. \& G. E. PETTS. 1993. Hydrosystèmes fluviaux. Collection d'écologie 24. Masson, Paris. $300 \mathrm{pp}$.

BATALLA, R. J. 2003. Sediment deficit in rivers caused by dams and instream gravel mining. A review with examples from NE Spain. Cuaternario y Geomorfología, 17(3-4): 79-91.

BEECHIE, T. J., M. LIERMANN, M. M. POLLOCK, S. BAKER \& J. DAVIES. 2006. Channel pattern and river-floodplain dynamics in forested mountain river systems. Geomorphology, 78: 124-141.

BLUM, M. D. \& T. E. TOÈRNQVIST. 2000. Fluvial response to climate and sea-level change: a review and a look forward. Sedimentology, 47 (Suppl.): 248.

BRANDT, S. A. 2000. Classification of geomorphological effects downstream of dams. Catena, 40: 375-401.

BRAVARD, J. P. \& G. E. PETTS. 1993. Interférences avec les interventions humaines. In: Hydrosystèmes fluviaux. Amoros, C. \& G. E. Petts (ed.): 233253. Collection d'écologie 24. Masson, Paris.

BRIERLEY, G. J. \& K. A. FRYIRS. 2005. Geomorphology and River Management. Blackwell Publishing. Singapore. 398 pp.

BROOKES, C. J., J. M. HOOKE \& J. MANT. 2000. Modelling vegetation interactions with channel 
flow in river valleys of the Mediterranean region. Catena, 40: 93-118.

CHARLTON, R. 2008. Fundamentals of fluvial geomorphology. Routledge. Abingdon. $234 \mathrm{pp}$.

CHURCH, M. 2002. Geomorphic thresholds in riverine landscapes. Freshwater Biology, 47: 541-557.

CHURCH, M. 2008. Multiple scales in rivers. In: Gravel-Bed Rivers VI: From Process Understanding to River Restoration. H. Habersack, H. Piégay \& M. Rinaldi (eds.): 3-27. Elsevier. Amsterdam.

COBO, R., J. L. GÓMEZ, A. PLATA, M. E. SANZ \& C. AVENDAÑO. 1996. Influencia del régimen de explotación del embalse de Puentes en las tasas de sedimentación durante el periodo 1954-1994. Actas V Jornadas Españolas de Presas: 155-169, Valencia.

DAY, J. W., E. MALTBY \& C. IBÁÑEZ. 2006. River basin management and delta sustainability: A commentary on the Ebro Delta and the Spanish National Hydrological Plan. Ecological Engineering, 26(2): 85-99.

DÍAZ, E. \& A. OLLERO. 2005. Metodología para la clasificación geomorfológica de los cursos fluviales de la cuenca del Ebro. Geographicalia, 47: 23-46.

DÍAZ, E., M. SÁNCHEZ, A. OLLERO, D. BALLARÍN \& D. MORA. 2006. Calidad hidromorfológica de los ríos de Aragón. Tecnología del agua, 278: 36-41.

DÍEZ HERRERO, A. 2003. Geomorfología e hidrología fluvial del río Alberche. Modelos y SIG para la gestión de riberas. Instituto Geológico y Minero de España. Madrid. 596 pp.

DOYLE, M. W. \& J. M. HARBOR. 2003. A scaling approximation of equilibrium timescales for sandbed and gravel-bed rivers responding to base-level lowering. Geomorphology, 54: 217-223.

ELOSEGI, A., L. FLORES, \& J. R. DÍEZ. 2011. The importance of local processes on river habitat characteristics; A Basque stream case study. Limnetica, 30(2): 183-196.

FAGOT, P., P. GADIOLET, M. MAGNE, \& J. P. BRAVARD. 1989. Etude de dendrochronologie dans le lit majeur de l'Ain: la forêt alluviale comme descripteur d'un changement morphodynamique. Revue de Géographie du Lyon, 4: 213223.

FISK, H. N. 1944. Geological investigation of the alluvial valley of the lower Mississippi River. River Commission. Viksburg, 78 pp.
FLORSHEIM, J. L., J. F. MOUNT \& L. T. RUTTEN. 2001. Effect of baselevel change on floodplain and fan sediment storage and ephemeral tributary channel morphology, Navarro River, California. Earth Surface Processes and Landforms, 26: 219-232.

FRIEDMAN, J. M., W. R. OSTERKAMP \& W. M. Jr LEWIS. 1996. The role of vegetation and bed-level fluctuations in the process of channel narrowing. Geomorphology, 14: 341-351.

GARCÍA-RUIZ, J. M. \& B. L. VALERO-GARCÉS. 1997. Procesos geomórficos históricos y su relación con la actividad humana en el Pirineo central español. Cuadernos de Investigación Geográfica, 22-23: 33-56.

GARZÓN, G., ORTEGA, J. A. \& J. GARROTE. 2010. Controles litológicos y estructurales en la jerarquización del drenaje. Las vegas del Guadiana. In: Avances de la Geomorfología en España, 20082010. XI Reunión Nacional de Geomorfología. X. Úbeda, D. Vericat \& R. J. Batalla (eds.): 373-376. Sociedad Española de Geomorfología.

GILVEAR, D. J. \& J. P. BRAVARD. 1993. Dynamique fluviale. In: Hydrosystèmes fluviaux. C. Amoros \& G. E. Petts (eds.): 61-82. Collection d'écologie 24, Masson. Paris.

GONZÁLEZ AMUCHASTEGUI, M. J. \& E. SERRANO. 2007. Evolución geomorfológica, cambios ambientales e intervención humana durante el Holoceno en la cuenca alta del Ebro: las tobas de los valles Purón y Molinar. Estudios Geográficos, LXVIII, 263: 527-546.

GONZÁLEZ PELLEJERO, R. 1986. Dinámica de un espacio natural: Los cañones calcáreos del Ebro (Burgos). Ería, 10: 5-86.

GREGORY, K. J. \& D. E. WALLING. 1973. Drainage basin form and processes. A geomorphological approach. Arnold, London. $472 \mathrm{pp}$.

GURNELL, A. M., I. P. MORRISSEY, A. J. BOITSIDIS, T. BARK, N. J. CLIFFORD, G. E. PETTS \& K. THOMPSON. 2006. Initial adjustments within a new river channel: interactions between fluvial processes, colonizing vegetation, and bank profile development. Environmental Management, 38: 580-596.

IBISATE, A. 2004. Las crecidas fluviales en el Zadorra: procesos, riesgos y propuestas de ordenación. Tesis doctoral. 630 pp. + anexo cartográfico. Inédito.

IBISATE, A., E. DÍAZ, V. ACÍN, D. GRANADO, A. OLLERO, A. REY, D. BALLARÍN, M. GIMENO, 
M. BALDISSONE, P. BESNÉ \& I. SÁNCHEZ. 2010. Estudio de alternativas de actuación de restauración de ríos y defensa frente a inundaciones en la zona de confluencia de los ríos Arga y Aragón. Estudio geomorfológico. Technical report. Universidad del País Vasco, Universidad de Zaragoza, ECOTER, S.C. Vitoria. 255 pp.

JUNK, W. J., P. B. BAYLEY \& R. E. SPARKS. 1989. The flood pulse concept in river-floodplain systems. Canadian Special Publication of Fisheries and Aquatic Science, 106: 110-127.

LANE, E. W. 1955. The importance of fluvial morphology in hydraulic engineering. American Society of Civil Engineering Proceedings, 81(745): 117.

LANE, S. N. \& K. S. RICHARDS. 1997. Linking river channel form and process: time, space and causality revisited. Earth Surface Processes and Landforms, 22: 249-260.

LEOPOLD, L. B. \& M. G. WOLMAN. 1957. River channel patterns: braided, meandering and straight. United States Geological Survey. Professional Paper, 282B: 39-85.

LÓPEZ-BERMÚDEZ, F. 2004. El Segura, la alteración del régimen de un río mediterráneo y su tendencia al debilitamiento. In: Alteración de los regímenes fluviales peninsulares. Gil Olcina, A. (coord.): 389-411. Fundación CajaMurcia. Murcia.

LÓPEZ-MORENO, J. I., S. BEGUERÍA, B. VALERO-GARCÉS \& J. M. GARCÍA-RUIZ. 2003. Intensidad de las avenidas y aterramiento de embalses en el Pirineo central español. Ería, 61: 159167.

MAHER, E. \& A. M. HARVEY. 2008. Fluvial system response to tectonically induced base-level changes during the late-Quaternary: The Rio Alias southeast Spain. Geomorphology, 100(1-2): 180 192.

MALAVOI, J. R., J. P. BRAVARD, H. PIÉGAY, E. HÉROIN \& P. RAMEZ. 1998. Determination de l'Espace de Liberté des Cours d'Eau. SDAGE Rhône-Méditerranée-Corse, Lyon, France. 39 pp.

MALDONADO, A. 1983. Dinámica sedimentaria y evolución litoral reciente del Delta del Ebro. In: Sistema integrado del Ebro. M. Mariño, M. (ed.): 33-60. Hermes. Madrid.

MARIÑO, M. G. 1990. Implications of climatic change on the Ebro Delta. In: Climatic change and the Mediterranean. L. Veftikc, J. D. Milliman \& G. Sestini (eds.): 304-327. Arnold, London.
MARTÍN-VIDE, J. P. (coord.) 2007. Informe sobre la propuesta de extracción de áridos en Belagua. UPC, UZ y UPV. Dpto. Medio Ambiente y Obras Públicas. Gobierno de Navarra. 4 pp.

MARTÍN-VIDE, J. P. \& C. M. BALDISSONE. 2010. Estudio morfodinámico del río Arga como consecuencia de su canalización. Technical report. Universitat Politècnica de Catalunya. Gestión Ambiental, Viveros y Repoblaciones de Navarra, S.A. Gobierno de Navarra. 69 pp.

MARTÍN-VIDE, J. P., FERRER-BOIX, C. \& A. OLLERO. 2010. Incision due to gravel mining: Modeling a case study from the Gállego River, Spain. Geomorphology, 117: 261-271.

MARTÍNEZ-CASTROVIEJO, R. \& J. M. GARCÍARUIZ. 1990. Coladas de piedras (debris flow) y dinámica fluvial en ríos torrenciales del Pirineo Central: el caso del río Ijuez. Cuadernos de Investigación Geográfica, 16: 55-72.

MARTÍNEZ-CASTROVIEJO, R., M. INBAR, A. GÓMEZ VILLAR \& J. M. GARCÍA-RUIZ. 1990. Cambios en el cauce aguas abajo de una presa de retención de sedimentos. I Reunión Nacional de Geomorfología. Teruel, Spain: 457-468.

MARTÍNEZ-CASTROVIEJO, R., A. GÓMEZ VILLAR \& J. M. GARCÍA-RUIZ. 1991. Ajustes fluviales derivados de cambios de usos del suelo en el Pirineo Aragonés. Cuaternario y Geomorfología, 5: 91-105.

MONTGOMERY, D. R. \& J. M. BUFFINGTON. 1998. Channel processes, classification, and response. In: River ecology and management: lessons from the Pacific Coastal ecoregion. Naiman, R. J. \& R. E. Bilby (eds.): 13-42. Springer-Verlag, New York.

NANSON, G. C. \& J. C. CROKE. 1992. A genetic classification of floodplains. Geomorphology, 4(6): 459-486.

NEWSON, M. D. 2002. Geomorphological concepts and tools for sustainable river ecosystem management. Aquatic Conservation: Marine and Freshwater Ecosystems, 12: 365-379.

OLLERO, A., E. DÍAZ, A. IBISATE, I. GORROTXATEGI, I. JUNGUITU \& A. SÁENZ DE OLAZAGOITIA. 2002. Delimitación y caracterización de áreas inundables por procesos de alta y media frecuencia en los cursos fluviales del Irati y el Aragón como base para la gestión de caudales. (Technical report). 39 pp. + cartografía.

OLLERO, A. (coord.). 2003. Metodología para la tipificación hidromorfológica de los cursos fluviales 
de Aragón en aplicaciones de la Directiva Marco de Aguas (2000/60/CE). Geographicalia, 44: 7-25. OLLERO, A. 2007. Alteraciones geomorfológicas en cauces. La restauración de sistemas fluviales afectados por canalizaciones y dragados. Estrategia $\mathrm{Na}$ cional de Restauración de Ríos. Technical report. Ministerio de Medio Ambiente. Madrid. 96 pp. http://marm.es/ca/agua/temas/delimitacion-y-restauracion-del-dominio-publico-hidraulico/Alteraciones_Geomorfologicas_de_rios_tcm8-27494.pdf

OLLERO, A. (coord.), E. DÍAZ, A. IBISATE, D. BALLARÍN, S. DOMENECH, J. FUENTES, J. HORACIO GARCÍA, L. GONZALO, D. MORA \& M. SÁNCHEZ. 2008. Efectos de las minicentrales hidroeléctricas en los sistemas fluviales de los ríos Aragón y Arga (tramos medio y bajo): diagnóstico, tendencias y propuestas de gestión. Estudio geomorfológico y de procesos fluviales. Technical report. Ibarra \& Jaso, \& Universidad de Zaragoza. 486 pp.

PIÉGAY, H. \& S. A. SCHUMM. 2003. System approaches in fluvial geomorphology. In: Tools in Fluvial Geomorphology. G. M. Kondolf \& H. Piégay (eds.): 105-134. Wiley. Chichester.

PIÉGAY, H., A. ALBER, L. SLATER \& L. BOURDIN. 2009. Census and typology of braided rivers in the French Alps. Aquatic Sciences, 71: 371.388.

RENWICK, W. H. 1992. Equilibrium, disequilibrium, and nonequilibrium landforms in the landscape. Geomorphology, 5: 265-276.

RINALDI, M. \& A. SIMON. 1998. Bed-level adjustments in the Arno River, central Italy. Geomorphology, 22: 57-71.

SCHULTE, L. 1996. Morfogénesis cuaternaria en el curso inferior del río de Aguas (cuenca de Vera. Provincia de Almería). In: IV Reunión de Geomorfología. O Castro (A Coruña). Grandal d'Anglade, A. \& J. Pagés Valcarlos (eds.): 223-236. Sociedad Española de Geomorfología.

SCHUMM, S. A. 1977. The fluvial system. Wiley. New York. 338 pp.

SCHUMM, S. A. 1988. Variability of the fluvial system in space and time. SCOPE: 35. In: Scales and Global Change: Spatial and Temporal Variability in Biospheric and Geospheric Processes. T. Ross- wall, R. G. Woodmansee \& P. G. Risser (eds.): 225-250. John Wiley \& Sons. Chichester. http:// www.icsu-scope.org/downloadpubs/scope35/chapter12.html

SCHUMM, S. A. 1993. River response to base level change: implications for sequence stratigraphy. Journal of Geology, 101: 279-294.

SCHUMM, S. A. 2005. River variability and complexity. Cambridge University Press. Cambridge. $220 \mathrm{pp}$.

SCHUMM, S. A. \& R. W. LICHTY 1965. Time, space and causality in Geomorphology. American Journal of Science, 263: 110-119.

SIMON, A. \& J. CASTRO. 2003. Measurement and Analysis of Alluvial Channel Form. In: Tools in Fluvial Geomorphology. G. M. Kondolf \& H. Piégay (eds.): 291-322. Wiley. Chichester.

SPRINGER, G. S., H. D. ROWE, B. HARDT, F. G. COCINA, R. L. EDWARDS \& H. CHENG. 2009. Climate driven changes in river channel morphology and base level during the Holocene and Late Pleistocene of southeastern West Virginia. Journal of Cave and Karst Studies, 71(2): 121-129.

THORNE, C. R. 1997. Channel Types and Morphological Classification. In: Applied Fluvial Geomorphology for River Engineering and Management. C. R. Thorne, R. D. Hey \& M. D. Newson (eds.): 175-222. John Wiley \& Sons, West Sussex, England.

TUROWSKI, J. M. N. HOVIUS, A. WILSON \& M. J. HORNG. 2008. Hydraulic geometry, river sediment and the definition of bedrock channels. Geomorphology, 99: 26-38.

VALERO-GARCÉS, B., A. NAVAS \& J. MACHÍN. 1996-97. Una aproximación sedimentológica al aterramiento de embalses y la erosión en cuencas de montaña: el embalse de Barasona y la cuenca de Esera-Isábera (Pirineos centrales, Huesca). Cuadernos de Investigación Geográfica, 22-23: 7-31.

VAUGHAN, I. P., M. DIAMOND, A. M. GURNELL, K. A. HALL, A. JENKINS, N. J. MILNER, L. A. NAYLOR, D. A. SEAR, G. WOODWARD \& S. J. ORMEROD. 2009. Integrating ecology with hydromorphology: a priority for river science and Management. Aquatic Conservation: Marine and Freshwater Ecosystems, 19: 113-125. 